\title{
Exploring Brand Identity and Entrepreneurship as Drivers of Small Specialist Retailer Internationalisation: A German Case Study
}

\author{
Helen Christmann, Andrew Alexander* and Steve Wood
}

\author{
Affiliation of all authors: \\ Department of Marketing and Retail Management \\ Surrey Business School \\ University of Surrey \\ Guildford \\ GU2 7XH \\ UK \\ * Corresponding author - email: $\underline{\text { A.Alexander@surrey.ac.uk }}$
}

This is the authors' accepted version prior to publishing in the International Review of Retail, Distribution and Consumer Research.

Please consult the journal version if citing.

\section{Acknowledgements}

The authors would like to thank the interview participants for their contributions to this study. Any errors or omissions remain the responsibility of the authors. 


\title{
Exploring Brand Identity and Entrepreneurship as Drivers of Small Specialist Retailer Internationalisation: A German Case Study
}

\begin{abstract}
While the comparatively sparse literature on small specialist retailing typically supports a proactive interpretation of the drivers of retail internationalisation, a more differentiated picture exists with regard to understanding the role of the brand construct in this process. The wider marketing literature recognises that brand identity, as well as brand image, can inform the process of internationalisation, yet research focusing on small specialist retail internationalisation remains under-developed in this regard. Neither the notion of a multi-faceted brand concept, nor its function as a strategic device in the internationalisation process has been analysed with sufficient depth. Furthermore, a better understanding of how and to what extent brand identity is interdependent upon the characteristics and activities of the entrepreneur is yet to emerge. This paper explores the construct of brand identity and its role within small specialist retail internationalisation, and the related influence of the entrepreneur on the internationalisation process. A case study approach is adopted, examining one German small specialist retailer. Data collection involved semi-structured interviews with owner managers and other senior management, an assessment of company documentation as well as participant observation, providing in-depth insights into distinctive internationalisation patterns. The study finds that a simple 'either-or' approach, in terms of characterising the retailer's motivation to internationalisation as being either reactive or proactive is inadequate in understanding this particular case. Whilst initial motivation was characterised as being reactive, the motivations underpinning further planned internationalisation are determined to be more proactive. More particularly, analysis reveals how brand identity is considered to play an important role in the internationalisation of the case study retailer, and highlights the numerous ways in which the characteristics and activities of the entrepreneurial owner-managers impact on the firm's internationalisation. This research contributes to retail and management research concerning SME internationalisation as well as to the retail-branding literature.
\end{abstract}

Keywords: Small to medium-sized enterprises (SMEs), International Retailing, Branding, International Entrepreneurship, SME Marketing.

\section{Introduction}

Hutchinson and Quinn $(2012,107)$ find that 'research that explores the internationalisation of small specialist retailers is surprisingly sparse given the number of specialist retailers with international operations'. This observation is yet more surprising when one considers that the identification of the driving forces underpinning retail internationalisation has been one of the main topics of research in international retailing during the last 20 years or so (Alexander and Doherty 2010). The research 
reveals that the drivers of retail internationalisation are many and often company-specific (Alexander 1995; Moore, Fernie, and Burt 2000; Williams 1992), and the notion that the brand itself can drive retail internationalisation has been widely reported (e.g. Moore, Fernie, and Burt 2000; Wigley, Moore, and Birtwistle 2005). This has led some to frame the internationalisation process as 'internationalising the brand' (Alexander and Doherty 2009, 102), particularly in relation to small specialist retailers within the fashion sector (Hutchinson et al. 2007).

The study by Hutchinson et al. (2007) to our knowledge was among the first to explore in more detail the factors motivating the internationalisation of small specialist retailers; although the internationalisation of specialist retailing has been considered more generally of course (Tordjman 1994; Simpson and Thorpe 1996). Hutchinson et al.’s (2007) study questions the somewhat limited interpretation of the role of the brand in internationalisation. Instead they give heightened significance to the internal dimension of the brand - brand identity - as a key motivator for international expansion (Hutchinson and Quinn 2012; Hutchinson et al. 2007). This mirrors discussion that can be found elsewhere within the broader retail branding literature that points to a failure to adequately distinguish between the term 'brand identity' and 'brand image' and hence a lack of clarity concerning the brand construct (Burt and Davies, 2010; Fetscherin and Usunier 2012; Mitchell, Hutchinson and Quinn 2013).

Given the role of the brand identity as the central antecedent, Hutchinson et al. (2007) simultaneously stress the insufficient attention given to this factor and the importance of internal and external facilitating factors as well as a parent-firm advantage. With regard to the brand identity, the authors highlight internal facilitating factors determining its development. These particularly relate to the crucial role of the entrepreneur, their international or global vision and mind-set, personality and 
personal networks in foreign markets. This is consistent with the broader retail branding literature that confirms the entrepreneur's central role to retail branding in terms of both symbolic and functional meaning across all aspects of retail SME business (Mitchell, Hutchinson, and Bishop 2012; Mitchell, Hutchinson and Quinn 2013).

To date then, despite some initial research, both the retail studies and the wider management literature concerning SME internationalisation remain under-developed, with neither the concept of the brand nor its function as a strategic device analysed with sufficient depth (e.g. Fetscherin and Usunier 2012; Hutchinson et al. 2012; Mitchell, Hutchinson and Quinn 2013; Moore and Doyle 2010; Sommer 2010; Toften and Hammervoll 2009). Furthermore, there is as yet insufficient understanding of how and to what extent the brand identity is interdependent upon, and relates to, the entrepreneur, her/his characteristics and activities.

Given the need for more understanding of small specialist retail internationalisation, this study addresses the role of the brand identity as a key driver of the internationalisation process. Taking a firm-level perspective, the paper explores what determines the distinctiveness of the brand identity within the competitive environment, and subsequently how the brand identity can constitute a competitive advantage in internationalisation. Attention is paid to company-specific factors that might influence internationalisation including entrepreneurial characteristics, such as degree of geocentricity and willingness for risk-taking, as well as the impacts of entrepreneurial networking. Of interest here is how these factors influence internationalisation either independently or together with the brand - for example by facilitating the development of the brand identity. Addressing the numerous calls for research conducted outside the UK and US (e.g. McAuley 2010; Hisrich and 
Drnovsek 2002; Hutchinson et al. 2007; Hutchinson and Quinn 2012), the paper presents case-study evidence from a German small specialist retailer.

The contribution of the study is twofold. First, it addresses the research gap relating to small specialist retail internationalisation by exploring the drivers behind the internationalisation of this particular type of retailer. Second, through a focus on the internal dimension of the brand construct, the research contributes to the field of retail branding to enhance our understanding of the role of the brand as a strategic device. In doing so, it responds to Hutchinson et al.'s $(2007,114)$ call for more exploration of 'the issue of branding in the internationalisation of retail SMEs, [and] the role of the entrepreneur and owner/manager in the international decision-making process of retail SMEs [...].'

The remainder of the paper is structured as follows. It begins with a literature review focussing on the discussion of the drivers of small specialist retail internationalisation. The following section explores the qualitative methodological approach adopted for this study. Findings from the qualitative study are then presented and subsequently discussed in relation to the research questions and literature. Recommendations are made as to key issues that demand future research.

\section{Literature Review}

\section{The role of brand identity in small specialist retail internationalisation}

The fashion retail sector represents a particular focus for those concerned with the internationalisation of small specialist retailers. In this context the important role of the fashion retail brand as a potential source of differential advantage for the retailer's national and also international development and growth becomes increasingly evident (Ailawadi and Keller 2004; Burt 2009; Fernie et al. 1998; 
Bridson and Evans 2004; McColl and Moore 2011; Moore, Fernie, and Burt 2000; Staake, Thiesse, and Fleisch 2009).

While the earlier business literature presented an extensive discussion on whether the motivation behind retail internationalisation was reactive or proactive in nature (Alexander and Doherty 2010; Johanson and Vahlne 1977, 1990; Johanson and Wiedersheim-Paul 1975; Robinson and Clarke-Hill 1990; Treadgold 1988, 1990), the fashion retailing literature typically emphasises the proactive nature of the internationalisation process and particularly focuses on the power of the brand in determining the differential advantage (e.g. Moore and Burt 2008; Moore, Fernie, and Burt 2000).

A study by Hutchinson et al. (2007) explored the internationalisation of small specialist retailers in order to identify the key motives and facilitating factors behind the decision to internationalise. They discuss the proactive nature of internationalisation for small specialist retailers and identify an opportunistic approach towards international development (see also Hutchinson et al., 2009). Furthermore, they find that the distinctiveness and the international appeal of a concept or brand can constitute a competitive advantage for small specialist retail internationalisation. As such, their study confirms the continued applicability of Simpson and Thorpe's (1996) conceptual model of the strategic considerations for the internationalisation of specialist retailers.

Hutchinson et al. (2007) attribute only limited explanatory power to possible constraints resulting from the size of the small specialist retailer and its likely limited resources. Instead, the authors highlight the role of the organisation behind the brand, and its interest and ambition to take the brand into the international market. Thus the company brand identity is identified as the key motivator for small specialist retail internationalisation, with a strong company brand image and 
identity viewed as a key characteristic of internationally successful small specialist retailers (Hutchinson and Quinn 2012, Hutchinson et al. 2009). The branding literature defines the brand identity as a 'form of group identity, which is expressed by a set of commonly shared values, competences, origin, vision, communication style and behaviour... [which] demarcates and differentiates the internal target group of a particular brand and therefore creates the substance of a brand' (Burmann, Hegner, and Riley, 2009, 115). Hutchinson et al.'s (2007) assessment of the influence of the company brand identity in internationalisation reflects how the conceptualisation of the retail brand itself has shifted over time, with an increased interest on the organisational dimension: 'from the product as a brand to the store as a brand and most recently to the organisation as a brand' (Burt and Davies 2010, 865).

While brand identity reveals an internal perspective in terms of brand promise and brand behaviour, brand image represents an external perspective in terms of the brand expectations and brand experience of consumers (Burmann, Hegner, and Riley 2009; Burt and Davies 2010). Burmann, Hegner, and Riley (2009) point out the importance of understanding the dynamic relationship between these two dimensions. However, on occasion, studies of the internationalisation of fashion retailers appear not to have fully specified this two-dimensional approach of the brand (e.g. Simpson and Thorpe 1996). Similarly the broader branding literature at times merely assumes an identity-based understanding towards branding (Burmann, Hegner, and Riley 2009; de Chernatony, 1999; Urde, 1999). Hence, the processes behind an identity-based understanding of branding remain underexplored both within the international retailing and the wider branding literature. An aspiration to contribute to this debate underpins the first research question of this study:

RQ1: What role does brand identity play in small specialist retail internationalisation? 


\section{The role of the entrepreneur in small specialist retail internationalisation}

\section{Innovativeness, proactivity and risk-taking}

Studies that focus on the role of brand identity in SME internationalisation identify a range of facilitating factors that influence the development of brand identity and serve to support expansion (Abimbola and Kocak, 2007; Hutchinson et al. 2007; Horan, O’Dwyer, and, Tiernan 2011; Mitchell, Hutchinson, and, Quinn 2013; Spence and Essoussi 2010). External facilitating factors include formal networking and partnering in foreign markets, consultancy assistance, along with parent company advantage to provide additional financial and intellectual capital. Internal facilitating factors determining the development of brand identity include the entrepreneurial personality, which encompasses the entrepreneurs' capacity to develop an international vision or mind-set, and the role of their personal networks in developing and sustaining international advantage. Our focus in this paper is on internal factors. Having considered the international business and the retail branding literature concerned with SMEs, it is these which we see as most pertinent in informing debate about the interface between brand development and internationalisation in small specialist retailing. We now turn to each of these internal facilitating factors in turn.

The international business literature in particular highlights the central role of the entrepreneur, and increasingly presents the SME internationalisation process as an entrepreneurial act per se (e.g. Acedo and Florin 2006; Kirkwood 2009; Schulz, Borghoff, and Kraus 2009). This has led to the emergence of International Entrepreneurship (IE) as a distinctive approach to the study of SME internationalisation, combining entrepreneurship, international business and international marketing research (Coombs, Sadrieh and Annavarjula 2009; Ruzzier and Hisrich 2006; Peiris, Akoorie and Sinha 2012; Wright, Westhead and Ucbasaran 2007). IE traditionally concerns the international 
orientation or behaviour of the founder toward development, with value creation based on innovativeness, proactivity and risk-taking (e.g. Amal and Filho 2010; Kirkwood 2009; Meliá, Pérez, and Dobón 2010; O‘Cass and Weerawardena 2009; Reuber and Fischer 1997). Broadly related dimensions such as competitive aggressiveness, autonomy and opportunism have also been suggested as important characteristics (Brown, Davidsson, and Wiklund 2001; Covin and Lumpkin 2011; Covin and Miller 2014; Sundqvist et al. 2012). As such, Lloyd-Reason and Mughan $(2002,126)$ argue: 'if the owner-manager is not willing to embark on a strategy of internationalisation, or finds such a strategy unacceptable, then there is little point in attempting to ensure that the enterprise is ready and able'.

Within the context of retail branding, Mitchell, Hutchinson, and Bishop (2012) similarly stressed the central role of the entrepreneur for the retail brand. Various studies have explored retailer examples in this respect, such as Laura Ashley, Richer Sounds and The Body Shop, underlining how the SME and its corresponding brand identity can come to symbolise the persona of the owner (Doole and Lowe 2008; Hutchinson, Quinn, and Alexander 2005; Kent and Stone 2007). Nonetheless, further detailed small specialist retailer case study analyses are required to enable us to enhance our understanding of how, and to what extent, IE facilitates the internationalisation process. This is particularly so when, as here in the instance of the German market, the case is drawn from a market which has furnished few empirical cases compared to those of the UK and US, and which has the potential to provide insight into the effects of different business cultures. The discussion above leads us to our second research question:

RQ2: How does entrepreneurial innovativeness, pro-activity and risk-taking behaviour influence small specialist retail internationalisation? 


\section{Entrepreneurial networking}

Another important internal factor relates to the capability of the entrepreneur to effectively access and network with international strategic partners (Agendal and Chetty 2007; Ellis 2010; Reuber and Fischer 1997). The international business literature identifies networking as important to our understanding of SME internationalisation (Ruzzier and Hisrich 2006). Networking refers to activities designed to gain access to market knowledge, and hence the identification of competitive opportunities in international markets, as well as knowledge that can inform the development and specification of operational procedures (Agendal and Chetty 2007; Amal and Filho 2010).

For Hutchinson et al. (2006), examination of the role of networking is especially relevant in considering the role of entrepreneurs of internationalising retail SMEs because decision-making processes are highly influenced by their personal networks in foreign markets. Similarly, Hutchinson et al. (2007) point to the importance of informal networking, as opposed to formal networking, in facilitating the internationalisation process. This stands in contrast to a variety of studies within the broader business literature, which place a greater relevance on formal business networking (e.g. Agendal and Chetty 2007; Westhead, Wright, and Ucbasaran 2001). Consequently, we explore the issue of networking in our case study analysis by considering the following question:

RQ3: How does informal entrepreneurial networking influence small specialist retail internationalisation? 


\section{Methodology}

\section{Research design}

A qualitative research design, and more particularly a case-study based approach is deemed most appropriate for this study. This reflects the comparatively underdeveloped nature of the area of enquiry, and the need for an intensive and in-depth exploration of the relevant phenomenon within its social context (Swanborn 2010; Yin 2009; Ridder, Hoon, and Baluch 2014). As such the study is consistent with recent scholarship focused on international retailing and international SMEs (e.g. Alexander and Doherty 2010; Evans et al. 2008). A quasi-inductive research approach was applied, reflecting the extent of knowledge and understanding within the subject area. As explained below, a single-case study design has been employed to enable us to take advantage of unusually extensive research access to a German small specialist retailer that was derived via a personal network. The depth of analysis possible from a single-case study can generate a high-level of understanding and help to build theory (Donnell, Hutchinson, and Reid 2012; Eisenhardt 1989; Eisenhardt and Graebner 2007; Patton 2002; Yin 2009). Nonetheless, the authors have been sensitive to the potential selection bias that a non-random single case selection might bring (Coombs, Sadrieh, and Annavarjula 2009; Goodwin and Horowitz 2002) and have been careful not to over-generalise based upon the study findings.

\section{Case background}

The company under investigation is a German small specialist retailer of leather goods accessories founded in 1891 as a retail business with its own tannery operation. It has remained majority familyowned and managed throughout its history. The company retails two own brands within the accessory sector, which carry small leather goods, business cases, backpacks, shoulder bags and travel bags for 
male and female consumers. Overall, the company has a headcount of less than 250 people and generates a turnover of less than $€ 50$ Million. As such the retailer conforms to the European Commission's (2013) definition of a SME. The chosen case study firm accords with the five key characteristics of small specialist retailers suggested by Hutchinson and Quinn $(2012,106)$ : 'a strong company brand image and identity, a niche strategy focussing on the middle and luxury market, a dual expansion strategy referring to both retail and wholesale activities, a dimension of ownership either characterised by the entrepreneur/founder or a parent company, as well as a vertical integration from manufacturing to retailing'. Consequently, the choice of case enhances the opportunity for inter-case comparison. Table 1 presents a company profile summarising key business information. The company follows a dual expansion strategy of wholesale distribution and the establishment of own retail stores that is fairly common within the sector. Following its establishment, the firm began to expand the supply of its goods into new markets in Germany and then internationally through a wholesaling operation. Retail expansion in the domestic market through new stores began in 2007, resulting in a network of ten stores in Germany. International expansion commenced within the EU in 2010 with the opening of stores at locations in two capital cities, Vienna and London.

** Take in Table 1. Domestic and international profile of case company **

\section{Data collection and analysis}

One-to-one, semi-structured interviews using open-ended questions were conducted with personnel of differing levels of management authority who oversaw and participated in the business strategy and decision-making processes related to the company's internationalisation (cf. Crouch and McKenzie 2006; Eisenhardt and Graebner 2007; Evans et al. 2008; Hutchinson et al. 2007). Interview questions 
in relation to research question 1 revolved around respondents' understanding of the brand construct and its elements, whether and how this construct motivated a proactive and opportunistic internationalisation, and whether and how such a construct was adjusted over time in order to meet the requirements of international retail markets. Interview questions in relation to research questions 2 and 3 addressed the two owner managers' characteristics as entrepreneurs and how these impacted on the branding strategy, as well as the operation of the retail business in the context of internationalisation.

Specifically, interviews were undertaken with the two owner-managers, one of whom is a direct descendant of the founding family, as well as with the senior marketing manager responsible for national and international brand management and the wholesale and retail manager of the firm's UK subsidiary. Interviews were recorded, transcribed and translated as the primary interview data was gathered in the interviewees' first language of German. Best practice on matters of language translation was adhered to (Temple and Young 2004; Weeks and Belfrage 2007). Interviewees were provided with preparatory and post-interview correspondence about the project to enable them to meaningfully consider and comment upon the project themes.

Documentary analysis of materials provided by the firm was also undertaken to support interpretation of the interviews; such materials included annual reports, internal strategy documents, marketing and PR material, and sales data. Data collection also included participant observation enabled by the lead author's employment in the case company, with the ethical requirements and potential limitations of such an approach fully acknowledged and observed (e.g. Arnould 1998; Saunders, Lewis and Thornhill 2009; Yin 2009). In doing so, the current study broadly mirrors approaches adopted elsewhere in the literature in applying a single-case study approach in a retail 
SME context by collecting data through semi-structured interviews, company documentation and onsite observation resulting from the researcher's embeddedness in the case, leveraging 'a close interaction with practitioners as a tool to generate and test theory' (Donnell, Hutchinson and Reid, 2012, 910). The validity of findings is enhanced by this analysis of multiple data sources as it helped to verify the insights gained from the interview material and to avoid the risks of overly subjective interpretation (see Chetty 1996; Gibbert and Ruigrok 2010; Gillham 2005; Patton 2002).

The data analysis process started alongside the data collection in order to consider unexpected but relevant themes not derived from the literature guiding this research (Saunders, Lewis and Thornhill 2009; Yin 2009). To develop insight into each of the study themes the case-study data analysis followed a quasi-inductive process mainly determined by the interpreting for meaning within each of the three meta-themes identified within the literature: the role of the brand identity, of the entrepreneur (in terms of innovativeness, proactivity and risk-taking), and of entrepreneurial networking (Easterby-Smith, Thorpe, and Jackson 2010; Hutchinson et al. 2007; Saunders, Lewis and Thornhill 2009; Yin 2009: 127). The technique of substantive coding was adopted for the interview data, and computer-assisted qualitative data analysis software (QSR NVIVO 10) was used to facilitate the coding process. The data from the interviews was independently coded by two of the research team to ensure inter-coder reliability in the process. After each coding round the coding team discussed results and the coding scheme was adapted and standardised for all coders. Quotations drawn from the interview data are used in the next section in order to illustrate the findings from the study (Holton 2010; Patton 2002). While company documentation primarily confirmed facts such as the time scale of internationalisation, countries entered, entry mode employed (Saunders, Lewis and Thornhill 2009; Yin 2009), insights from participant observation provided access to decision-making 
processes beyond internationalisation thus allowing the authors to better understand the case context in which internationalisation patterns are explored.

\section{Findings}

\section{The role of brand identity in small specialist retail internationalisation}

Evaluation of the firm's motivations for initial retail internationalisation points to a combination of reactive and proactive interpretations. It is clear that internationalisation is closely linked to the ownermanagers' perception of there being only limited opportunities for additional retail turnover in domestic markets. One interviewee stressed that internationalisation of retail operations occurred 'actually, just because of this' (Interviewee 2); retail operations needed to be internationalised. However, the owner-manager extended the discussion by reflecting on the desire for further international market growth, and expressing their opinion as to the potential of the brand in enabling successful internationalisation:

'I think that without an international orientation, $[\ldots]$ we would not be able to sustain our business. We want to generate future turnover in these [international] regions... I am of the opinion that the possibilities for our brands [in these regions] are not bad at all' (Interviewee 2).

The significance of the brand identity as a motivating factor in the decision to internationalise was further commented upon by another interviewee in discussing how UK retail store staff sometimes sought to communicate the brand message to their customers: 'Yes, there was a lot of staff that we had that loved the heritage, that loved the idea that the brand had been going for over 100 years, that we still have something quite unique in terms of this aspect' (Interviewee 4). 
The interviewees also explained their opinions as to how knowledge accumulated over generations brings a unique product competence, setting the retailer apart from national and international competition and contributing to brand identity. For example:

'There are of course competitors and people that do similar things like us, [namely] business bags. However, there is no-one dealing with this matter as in-depth as we do' (Interviewee 1).

This unique competence enables the exploration of innovative approaches towards product development that best reflect changes in international consumer demand in the product sector. As a result, these approaches have the potential to help to sustain existing international retail presence and to provide opportunities for further international retail expansion. As one interviewee explained:

'I think that this is a product you can wear around the globe. And I also think that there are other countries, which are more advanced than us. In the sense that there is more [consumer] acceptance than in Germany' (Interviewee 1).

This advantage based on specialisation has been utilised along with a German image in the market during retail internationalisation. Some of the interviewees expressed a view that the retail brand and its products conveyed certain qualities, which they considered consumers might associate with German business: 'right back from the start the key values were it's traditional, it's reliable, it's functional' (Interviewee 4). The elaboration of a country-of-origin effect (COO) is considered to offer the retailer a unique selling position within consumer markets: 'Because it is different with us. [...] 
You buy a leather bag from Italy when you are buying a bag. Not really from Germany, so that's why it is important' (Interviewee 1). One owner-manager elaborated upon the influence of a German image on international market demand whilst nonetheless identifying the need for adaption in international market operations and observing that 'retail is local':

'In England, we present ourselves much more conservative and, yes, we tell the story of the old company, whereby tradition is very important. German tradition [...] I am excited how the English people are reacting. We are presenting ourselves as a German business and, yes, I think people acknowledge that' (Interviewee 2).

Overall then such brand promise or brand behaviour remains a key driver for proactive retail internationalisation as one interviewee explains:

'...we have just opened a store in London. We are positive about the brand [...] That is why we are continuing the way into foreign markets offensively and are opening another store in [...] Vienna' (Interviewee 1).

In addition, the interviewees suggest an important reciprocal interplay between the brand concept and the internationalisation process; they observe a positive effect on the brand and organisation that is derived from internationalisation:

'This is due to the fact that these stores in these locations usually don't help you generating that much money, but rather help you to transport the name. Then, everything makes sense 
again $[\ldots]$. But without this, I cannot imagine how to establish a stable brand name' (Interviewee 2).

Clearly then, brand identity is an important factor in the process of internationalisation. Nonetheless, the interviewees also reflect upon its limits in this regard and identify other factors that constrain internationalisation, such as the retailer's limited financial and managerial resources. In relation to the latter, the pro-active response of personnel within the organisation and their affinity to the brand is stressed: 'It is about the personal effort, with all that matters' (Interviewee 2). This leads us to consideration of our second main theme, the role of the entrepreneur.

\section{The role of the entrepreneur in small specialist retail internationalisation}

\section{Entrepreneurial innovativeness, proactivity and risk-taking}

The contributions of the interviewees reveal the relevance of the owner-managers' characteristics and behaviours as entrepreneurs, including their entrepreneurial networking, in explaining the process of retail internationalisation by the firm. The central role of the two ownermanagers as entrepreneurs within the management structure of the SME and their ties with the heritage of the family firm is widely remarked upon in the interviews, albeit from different perspectives of course. For example, one interviewee emphasised how the brand symbolised the entrepreneurs, explaining that for them 'the two are the brand' (Interviewee 1). Consequently, the innovativeness, proactivity and risk-taking orientation of the entrepreneurs in many ways becomes an integral part of the brand identity that shapes the firm's internationalisation behaviour. 
Especially during the initial internationalisation, the innovativeness of the entrepreneurial behaviour of the owner-founders, including their apparent geocentric outlook, was perceived as important in explaining the decision to enter new markets, '[name of owner-founder] is the sort of person who just does not think within certain boundaries, he thinks globally' (Interviewee 1). More particularly, in explaining the initial move into the British market, one contributor reflected upon how the significance of the firm's unique selling proposition was the result of the entrepreneurialism of the owner-managers in recognising a gap in the niche market of leather goods accessories. He suggested:

'...there wasn't really anything major in the men's accessory [sector], in this part of it, in particular in an everyday bag. And I think it was well ahead of the game to start with.' (Interviewee 4)

Whilst the coalescence of the entrepreneur and the brand can bring benefits including innovation and pro-action, it is not without potential difficulties such as in the communication of the entrepreneurial vision of the brand to other employees. As one contributor observed in relation to the case study firm:

'I think they can't exactly communicate this. They have this in their mind, and I perceive them agreeing on this, but, I think we asked them once to write this down so that everyone can really get it. But they couldn't.' (Interviewee 1)

In relation to the motivation to seek expansion through new international markets one of the owner-managers interviewed offered explanation for he and his owner-manager partner's pro-activity in this regard. His contribution reveals the often personal and particular nature of such motivations: 
'It is manifold. Well, at first it is our personal motivation. If we had not wanted it, it would not have happened"

'We wanted to create something that is worth or maybe interesting for our children to take into the next generation and which is fun to do so. This is very meaningful. We didn't want to make a quick pound.... I understood what it means for [owner-manager partner] yes, it is her family business we took over and I realised from the beginning that it is important to her that we don't just milk the company and get money out of it' (Interviewee 2).

Observation in relation to matters other than internationalisation revealed that such a longterm approach, that is to say an inter-generational perspective to business development, is central to their entrepreneurial decision-making.

In reviewing their management of the business and the internationalisation of its activities, both owner-managers commented upon the importance of risk-tolerance. One interviewee offered an explanation for such tolerance on the basis that one of the owner-managers had themselves grown up in a family that displayed an entrepreneurial culture (Interviewee 2). Interestingly however, interviewees also remarked upon the effects of an insolvency that the firm experienced in the mid1990s in leading to a more conservative conditioning of the owner-managers' subsequent outlook on risk. One owner-manager explained: 'Considering our previous experiences, today I am more risk averse, well, risk averse might be saying too much, but I am considerate' (Interviewee 2). 


\section{Entrepreneurial networking}

Finally we turn to the theme of personal networking by entrepreneurs which the literature considers to be an important driver of small specialist retailer internationalisation, particularly with regard to how it is underpinned by shared values and realised in shared communication. The perceived benefits of personal networking can be traced back to a shared business and life philosophy that can lead to deep understanding and trust. It is believed that relationships developed on such a level can overcome economic cycles and ensure sustainability of a business perhaps better than those emanating from strictly formal business relationships: '[...] you might experience ups and downs. It is about the people trusting you, without leaving the sinking ship when in fact it only has a bit of a list' (Interviewee 2). Both owner-managers placed emphasis upon the importance of relationships developed through personal networking in underpinning the growth and internationalisation of the business. One respondent contended that their experiences within the business led them to consider that shared values and trust were essential to success: 'The step to [name of market] developed solely out of the personal contact $[\ldots]$ the trust and belief to enter the market was dependent on the personality of [name]...' (Interviewee 3). In the same light, it was explained by our interviewees that selected other foreign target markets had been passed over for international expansion based on the lack of a sufficiently robust personal network.

This is not to suggest that contributors did not recognise the possible shortcomings of an approach based solely upon personal trust and networks:

'[Y]ou can't underestimate the strength of the family bond or the friendship bond. It is the same sort of thing, which I think in so many ways is such a nice thing to experience, but sometimes, I think judgements can be made, which aren't necessarily right for the business 
$[\ldots]$ I would say sometimes the heart ruled the head $[\ldots]$ and in business that doesn't always work' (Interviewee 4).

\section{Discussion and Conclusions}

The findings from this study yield new empirical insights into the drivers of small specialist retail internationalisation and how the different drivers both individually and when operating together influence the internationalisation process. The international retailing literature highlights the varied nature of the motivations behind retail internationalisation (Alexander and Doherty 2010; Moore and Burt 2008). This study finds a simple 'either-or' approach - that is to say presenting the motivation for internationalisation as either one of reaction or one of pro-action - to be inadequate in the case of this particular retailer, at least as it is perceived by those most closely connected with such activity. Much of the initial motivation might have been borne of reaction to perceived limited opportunities within the German home market, but it is clear from our study and the contribution of the interviewees that this narrative quickly became fused with others, more characterised by pro-action as well as elements of opportunism (Dawson 1994, 2001). In this regard the role of the brand identity as a key driver of internationalisation was important, being widely perceived to offer opportunities to grow turnover through trading in international markets. Moreover, the case study reveals how brand identity development and internationalisation were considered as potentially symbiotic activities; retail internationalisation being considered necessary for the development of a corporate brand identity and image suitable for today's consumer market.

Analysis of the case study reveals how brand identity played an important role in the internationalisation of the small specialist German retailer (Research question 1); particularly how 
aspects of the brand concept can provide the firm with competitive advantage when expanding operations from domestic to international markets. This finding is consistent with other studies into fashion and other small specialist retailing (e.g. Burt and Davies 2010; Fernie et al. 1998; Hutchinson et al. 2007; McColl and Moore 2011; Moore, Fernie, and Burt 2000). It is clear that the managers within the firm that we interviewed perceived a key strength of the brand identity to be the combination of the business's history of specialisation within one product segment and what they saw as the firm's particular German image. This combination was considered to place the retailer into a niche position, making it distinctive from its competitors.

Analysis of the case study reveals the entrepreneur as an important dimension of small specialist retail internationalisation and also highlights the numerous ways in which the characteristics and activities of the entrepreneurial owner-managers impact this process (Research questions 2 and 3). First, and related to the discussion above, the study reveals clearly the centrality of the entrepreneur to the creation, development and management of the retail brand identity (Hutchinson and Quinn 2012; Mitchell, Hutchinson, and Bishop 2012; Spence and Essoussi 2010). As a result, in this case, as in others, the brand identity was considered by some to have come to symbolise the firm's owners (Kent and Stone 2007). More particularly, it shows the intimate ties between family-ownership, the brand's heritage and its planned development (see also Kontinen and Olaja 2012). The authors relate this to the institutional context of the German case study. Despite the apparent convergence of markets in the light of the forces of globalisation, institutional differences across nations lead to distinctiveness in the economic sphere (e.g. Whitley 2001). Ferner, Quintanilla, and Varul (2001) emphasise a range of features of the German model that make it distinctive from the Anglo-Saxon model including a 'longtermist' approach, which as they observe reflects, amongst other factors, the importance of family ownership and the significance of the family entrepreneur. 
Second, other interviewees identify what they consider to be innovative activities in the marketplace by the owner-managers, and also a geocentric orientation among them that facilitates the exploitation of innovation through internationalisation. Third, personal networking by the ownermanagers is seen as an important underpinning to the firm's international retail and wholesale activity with trust identified as crucial in explaining the development and maintenance of these networks (see Colli, García-Canal, and Guillén 2013; Fink and Kraus 2007; Sasi and Arenius 2008). Focusing on the firm's retail activities, the case illustrates how evaluations of the strength and potential of existing personal networks have directly influenced the processes of internationalisation and the direction of the firm's international retail expansion. This is significant given that effective informal networking is shown to provide access to market knowledge, and consequently the identification of competitive opportunities, as well as providing knowledge that can benefit operational procedures (see also Amal and Filho 2010 Chandra, Styles, and Wilkinson 2012; Hutchinson, Quinn, and Alexander 2006; Terziovski 2003). Consequently, this case study analysis provides important empirical evidence of how and why an understanding of the characteristics and activities of the entrepreneur ownermanagers is fundamental to any consideration of the internationalisation of the SME and its brand(s) (see also Lloyd-Reason and Mughan 2002; Mitchell, Hutchinson, and Bishop 2012; O`Cass and Weerawardena 2009). Nevertheless, while the influences of such characteristics upon the firm are often positive, they are not without their challenges and potential for conflict.

A limitation of our study is that the single case study approach restricts the degree to which we can generalise from our results. Nevertheless, our findings point toward a number of topics that warrant further study by researchers interested in the study of international retailing. We limit our discussion here to two of these which we consider to offer real benefits to understanding of the issues 
to hand. First, we need to know more about the role of trust in the development of personal networks, which, as is clear from this study, can have a significant impact on the processes of internationalisation generally, and on the direction of international expansion more particularly. Second, the symbioticlike relationship we identify between brand development and internationalisation deserves further study given its potential to inform theorisation on the internationalisation of small specialist retailers and because of its practical significance to such firms which represent an important part of the European retail market.

\section{References}

Abimbola, T., and A. Kocak. 2007. "Brand, Organization Identity and Reputation: SMEs as Expressive Organizations." Qualitative Market Research: An International Journal 10 (4): 416-430.

Acedo, F.J., and J. Florin. 2006 "An Entrepreneurial Cognition Perspective on the Internationalization of SMEs.” Journal of International Entrepreneurship 4 (1): 49-67.

Agendal, H., and S. Chetty. . 2007. "The Impact of Relationships on Changes in Internationalisation Strategies of SMEs.” European Journal of Marketing 41 (11/12): 1449-1474.

Ailawadi, K.L., and K. Keller. 2004. “Understanding Retail Branding: Conceptual Insights and Research Priorities.” Journal of Retailing 80: 331-342.

Alexander, N. 1995. "Expansion within the Single European Market: A Motivational Structure." International Review of Retail, Distribution and Consumer Research 5 (4): 472-487.

Alexander, N., and A.M. Doherty. 2009. International Retailing. Oxford: Oxford University Press

Alexander, N., and A.M. Doherty. 2010. "International Retail Research: Focus, Methodology and Conceptual Framework.” International Journal of Retail \& Distribution Management 38 (11/12): 928-942.

Amal, M., and A.R.F. Filho. 2010. "Internationalisation of Small- and Medium-Sized Enterprises: a Multi Case Study." European Business Review 22 (6): 608-623. 
Arnould, E.J. 1998. "Ethical Concerns in Participant Observation/Ethnography." Advances in Consumer Research 25 (1): 72-74.

Bridson, K., and J. Evans. 2004. "The Secret of a Fashion Advantage is Brand Orientation" International Journal of Retail \& Distribution Management 32 (8): 403-411.

Brown, T.E., P. Davidsson, and J. Wiklund. 2001. “An Operationalization of Stevenson's Conceptualization of Entrepreneurship as Opportunity-based Firm Behaviour." Strategic Management Journal 22(10): 953-968.

Burmann, C., S. Hegner, and N. Riley. 2009. "Towards an Identity-based Branding." Marketing Theory 9 (1): 113-118.

Burt, S. 2009. "Retailing in Europe: 20 years on.” The International Review of Retail, Distribution and Consumer Research 20 (1): 9-27.

Burt, S., and K. Davies. 2010. "From the Retailer Brand to the Retail-er as a Brand: Themes and Issues in Retail Branding Research.” International Journal of Retail \& Distribution Management 38 (11/12): 865-878.

Chandra, Y., C. Styles, and I. Wilkinson. 2012. "An Opportunity-Based View of Rapid Internationalization.” Journal of International Marketing 20 (1): 74-102.

Chetty, S.K. 1996. "The Case-Study Method for Research in Small- and Medium-sized Firms." International Small Business Journal 15 (73): 73-85.

Colli, A., E. García-Canal, and M. F. Guillén. 2013. "Family Character and International Entrepreneurship: A Historical Comparison of Italian and Spanish 'New Multinationals'." Business History 55 (1): 119-138.

Coombs, J. E., F. Sadrieh, and M. Annavarjula. 2009. “Two Decades of International Entrepreneurship Research: What Have We Learned - Where Do We Go From Here?” International Journal of Entrepreneurship 13: 23- 64.

Covin, J.G., and G.T. Lumpkin. 2011. "Entrepreneurial Orientation Theory and Research: Reflections on a Needed Construct." Entrepreneurship Theory and Practice 35 (5): 855-872. Covin, J.G., and D. Miller. 2014. "International Entrepreneurial Orientation: Conceptual Considerations, Research Themes, Measurement Issues, and Future Research Directions.” Entrepreneurship Theory \& Practice 38 (1): 11-44.

Crouch, M., and H. McKenzie. 2006. "The Logic of Small Samples in Interview-based Qualitative Research.” Social Science Information 45 (4): 483-499. 
Dawson, J.A. 1994. "Internationalization of Retailing Operations.” Journal of Marketing Management 10: 267-282.

Dawson, J.A. 2001. "Strategy and Opportunism in European Retail Internationalization.” British Journal of Management 12 (4): 253- 266.

De Chernatony, L. 1999. "Brand Management Through Narrowing the Gap Between Brand Identity and Brand Reputation.” Journal of Marketing Management 15 (1-3): 157-179.

Donnell, L., K. Hutchinson, and A. Reid. 2012. "Fashion Retailing in the New Economy: The Case of SMEs.” International Journal of Retail and Distribution Management 40 (2): 906-919.

Doole, I., and R. Lowe. 2008. International Marketing Strategy: Analysis, Development and Implementation, $5^{\text {th }}$ ed. London: Cengage Learning EMEA.

Easterby-Smith, M., R. Thorpe, and P.R. Jackson. 2010. Management Research. 3rd ed. London: Sage Publications Ltd.

Eisenhardt, K.M. 1989. "Building Theories from Case Study Research.” Academy of Management Review 14: 532-550.

Eisenhardt, K.M, and M.E. Graebner. 2007. "Theory Building from Cases: Opportunities and Challenges." Academy of Management Journal 50 (1): 25-32.

Ellis, P. 2010. "Social Ties and International Entrepreneurship: Opportunities and Constraints Affecting Firm Internationalization.” Journal of International Business Studies 42 (1): 99127.

European Commission. 2013. "A Recovery on the Horizon? - Annual Report on European SMEs 2012/13.” Enterprise and Industry Publications. Accessed August 132014. http://ec.europa.eu/enterprise/policies/sme/facts-figures-analysis/performancereview/index_en.htm

Evans, J., K. Bridson, J. Byrom, and D. Medway. 2008. "Revisiting Retail Internationalisation: Drivers, Impediments and Business Strategy.” International Journal of Retail and Distribution Management 36 (4) 260-280.

Ferner, A., J. Quintanilla, and M. Z Varul. 2001. "Country-of-origin effects, host-country effects, and the management of HR in multinationals: German companies in Britain and Spain." Journal of World Business 36 (2): 107-127. 
Fernie, J., C. Moore, A. Lawrie, and A. Hallsworth. 1997. "The Internationalization of the High Fashion Brand: the Case of Central London.” Journal of Product \& Brand Management 6 (3): 151-12.

Fernie, J., C. Moore, A. Lawrie, and A. Hallsworth. 1998. “A Tale of Two Cities: An Examination of Fashion Design Retailing within London and New York.” Journal of Product \& Brand Management, 7 (5): 366-378.

Fetscherin, M., and J-C. Usunier. 2012. "Corporate Branding: an Interdisciplinary Literature Review.” European Journal of Marketing 46 (5): 7-7.

Fink, M., and S. Kraus. 2007. "Mutual Trust as a Key to Internationalization of SMEs." Management Research News 30 (9): 674-688.

Gibbert, M., and W. Ruigrok. 2010. “The 'What' and 'How' of Case Study Rigour: Three Strategies based on Published work." Organizational Research Methods 13 (4): 710-737.

Gillham, B. 2005. Research Interviewing: The Range of Techniques. Berkshire: McGraw-Hill Education.

Goodwin, J., and R. Horowitz. 2002. "Introduction: The Methodological Strengths and Dilemmas of Qualitative Sociology." Qualitative Sociology 25 (1): 33- 47.

Hisrich, R., and M. Drnovsek. 2002. "Entrepreneurship and Small Business Research - a European Perspective." Journal of Small Business and Enterprise Development 9 (2): 172-222.

Holton, J.A. 2010. "The Coding Process and its Challenges." The Grounded Theory Review 9 (1): 1542-1556.

Horan, G., M. O’Dwyer, and S. Tiernan. 2011. "Exploring Management Perspectives of Branding in Service SMEs.” Journal of Services Marketing 25 (2): 114-121.

Hutchinson, K., N. Alexander, B. Quinn and A.M. Doherty. 2007. "Internationalization Motives and Facilitating Factors: Qualitative Evidence from Smaller Specialist Retailers.” Journal of International Marketing 15 (3): 96-122.

Hutchinson, K., and B. Quinn. 2012. "Identifying the Characteristics of Small Specialist International Retailers” European Business Review 24 (2): 106-119.

Hutchinson, K., B. Quinn, and N. Alexander. 2005. "The Internationalisation of Small to MediumSized Retail Companies: Towards a Conceptual Framework.” Journal of Marketing Management 21: 149-179. 
Hutchinson, K., B. Quinn, and N. Alexander. 2006. "SME Retailer Internationalisation: Case Study Evidence from British Retailers.” International Marketing Review 23 (1): 25-53.

Hutchinson, K., B. Quinn, N. Alexander, and A.M. Doherty. 2009. "Retailer Internationalization: Overcoming Barriers to Expansion.” The International Review of Retail, Distribution and Consumer Research 19 (3): 251-272

Johanson, J., and J.-E. Vahlne. 1977. "The Internationalization Process of the Firm - a Model of Knowledge Development and Increasing Foreign Market Commitments.” Journal of International Business Studies 8 (1): 23-32.

Johanson, J., and J.-E. Vahlne. 1990. “The Mechanism of Internationalisation.” International Marketing Review 7 (4): 11-24.

Johanson, J., and F. Wiedersheim-Paul.1975. "The Internationalisation of the Firm- Four Swedish Cases." Journal of Management Studies 12: 305-322.

Kent, T., and D. Stone. 2007. "The Body Shop and the Role of Design in Retail Branding." International Journal of Retail and Distribution Management 35 (7): 531-543.

Kirkwood, J. 2009. “To Grow or Not? Growing Small Service Firms.” Journal of Small Business and Enterprise Development 16 (3): 485-503.

Kontinen, T., and A. Ojala. 2012. "Internationalization Pathways among Family-owned SMEs." International Marketing Review 29 (5): 496- 518.

Lloyd-Reason, L., and T. Mughan. 2002. "Strategies for Internationalisation within SMEs: The Key Role of the Owner-manager." Journal of Small Business and Enterprise Development 9 (2): 120-129.

McAuley, A. 2010. "Looking Back, Going Forward: Reflecting on Research into the SME Internationalisation Process." Journal of Research in Marketing and Entrepreneurship 12 (1): $21-41$.

McColl, J., and C.M. Moore. 2011. "An Exploration of Fashion Retailer own Brand Strategies." Journal of Fashion Marketing and Management 15 (1): 91-107.

Meliá, M.R., A.B. Pérez, and S.R. Dobón. 2010. “The Influence of Innovation Orientation on the Internationalisation of SMEs in the Service Sector.” The Service Industries Journal 30 (5): 777-791.

Mitchell, R., K. Hutchinson, and S. Bishop. 2012. "Interpretation of the Retail Brand: An SME Perspective." International Journal of Retail and Distribution Management 40 (2): 157-175. 
Mitchell, R., K. Hutchinson and, B. Quinn. 2013. "Brand Management in Small and Medium-sized (SME) Retailers: A Future Research Agenda.” Journal of Marketing Management 29 (1112): $1367-1393$.

Moore, C.M., and S. Burt. 2008. "Developing a Research Agenda for the Internationalization of Fashion Retailing” In Fashion Marketing: Contemporary Issues edited by Hines, T., and M. Bruce, 89-106. Oxford: Butterworth-Heinemann (Elsevier).

Moore, C.M., and S.A. Doyle. 2010. "The Evolution of a Luxury Brand: The Case of Prada." International Journal of Retail \& Distribution Management 38 (11/12): 915-927.

Moore, C.M., J. Fernie, and S. Burt. 2000. "Brands without Boundaries: The Internationalisation of the Designer Retailer's Brand.” European Journal of Marketing 34 (8): 919-937.

O‘Cass, A., and J. Weerawardena. 2009. "Examine the Role of International Entrepreneurship, Innovation and International Market Performance in SME Internationalisation.” European Journal of Marketing 43 (11/12): 1325-134.

Peiris, I.K., M.E.M. Akoorie, and P. Sinha. 2012. "International Entrepreneurship: A Critical Analysis of Studies in the Past two Decades and Future Directions for Research.” Journal of International Entrepreneurship 10 (4): 279-324.

Patton, M.Q. 2002. Qualitative Research and Evaluation Methods. 3rd ed. London: Sage Publications.

Reuber, A.R., and E. Fischer. 1997. “The Influence of the Management Team's International Experience on the Internationalisation Behaviors of SMEs.” Journal of International Business Studies 28 (4): 807-825.

Ridder, H.-G., C. Hoon, and A. M. Baluch. 2014. "Entering a Dialogue: Positioning Case Study Findings towards Theory." British Journal of Management 25 (2): 373-387.

Robinson, T.M., and C.M. Clarke-Hill. 1990. "Directional Growth by European Retailers." Journal of Retail and Distribution Management 18 (5): 3-14.

Ruzzier, M., and B. Hisrich. 2006. "SME Internationalisation Research: Past, Present, and Future." Journal of Small Business and Enterprise Development 13 (4): 476-497.

Sasi, V., and P. Arenius. 2008. "International New Ventures and Social Networks: Advantage or Liability?” European Management Journal 26: 400-411.

Saunders, M., P. Lewis, and A. Thornhill. 2010. Research Methods for Business Students. 5th ed. Essex: Pearson Education Ltd. 
Schulz, A., T. Borghoff, and S. Kraus. 2009. "International Entrepreneurship: Towards a Theory of SME Internationalisation.” International Journal of Business and Economics 9 (1): 1-12.

Sigfusson, T., and S. Harris. 2012, “The Relationship Formation Paths of International Entrepreneurs.” Journal of International Entrepreneurship 10: 325-249.

Simpson, E.M., and D.I. Thorpe. 1996. “A Conceptual Model of Strategic Considerations for International Retail Expansion.” Service Industries Journal 15 (4): 16-24.

Sommer, L. 2010. "Internationalization Processes of Small- and Medium-sized Enterprises-a Matter of Attitude?” Journal of International Entrepreneurship 8: 288-317.

Spence, M., and L.H. Essoussi. 2010. "SME Brand Building and Management: An Exploratory Study." European Journal of Marketing 44 (7/8): 1037-1054.

Staake, T., F. Thiesse, and E. Fleisch. 2009. "The Emergence of Counterfeit Trade: A Literature Review." European Journal of Marketing 43 (3/4): 320-349.

Sundqvist, S., K. Kyläheiko, O. Kuivalainen, and J.W. Cadogan. 2012. "Kirznerian and Schumpeterian Entrepreneurial-oriented Behaviour in Turbulent Export Markets." International Marketing Review 29 (2): 203-229.

Swanborn, P. 2010. Case Study Research: What, Why and How? London: SAGE Publications Ltd. Temple, B., and A. Young. 2004. "Qualitative Research and Translation Dilemmas.” Qualitative Research 4 (2): 161-178.

Terziovski, M. 2003. "The Relationship between Networking Practices and Business Intelligence: A Case Study of Small to Medium Enterprises (SME).” Measuring Business Excellence 7 (2): 78-92.

Toften, K., and T. Hammervoll. 2010. "Niche Marketing and Strategic Capabilities: An Exploratory Study of Specialist Firms.” Market Intelligence and Planning 28 (6): 726-753.

Tordjman, A. 1994. "European Retailing: Convergences, Differences and Perspectives." International Journal of Retail and Distribution Management 22 (5): 3-19.

Treadgold, A. 1988. "Retailing without Frontiers: The Emergence of Transnational Retailers." Retail and Distribution Management 16 (6): 8-12.

Treadgold, A. 1990. "The Developing Internationalisation of Retailing." International Journal of Retail and Distribution Management 18 (2): 4-11.

Urde, M. 1999. "Brand Orientation: A Mindset for Building Brands into Strategic Resources." Journal of Marketing Management 15 (1-3): 117-133. 
Weeks, A., and J. Belfrage. 2007. "Issues, Challenges and Solutions in Translating Study Instruments." Evaluation Review 31 (2): 153-165.

Westhead, P., M. Wright, and D. Ucbasaran. 2001. "The Internationalisation of New and Small Firms: A Resource-based View.” Journal of Business Venturing 16: 333-358.

Wigley, S.M., C.M. Moore, and G. Birtwistle. 2005. "Brand and Product: Critical Success Factors in the Internationalisation of a Fashion Retailer." International Journal of Retail, Distribution and Management 33 (7): 531-544.

Whitley, R. 2001. "How and why are International Firms Different? The Consequences of CrossBorder Managerial Coordination for Firm Characteristics and Behaviour.” In G. Morgan, P. H. Kristensen \& R. Whitley (Eds.), The Multinational Firm: Organizing Across Institutional and National Divides: 27-68. Oxford: Oxford University Press.

Williams, D.E. 1992. "Retailer Internationalization: An Empirical Inquiry.” European Journal of Marketing 26 (8/9): 8-24.

Wright, M., P. Westhead, and D. Ucbasaran. 2007. "Internationalization of small and medium-sized enterprises (SMEs) and international entrepreneurship: A critique and policy implications.” Regional Studies, 41 (7), 1013-1030.

Yin, R.K. 2009. Case Study Research: Design and Methods. 4th ed. London: Sage Publications Ltd. 
Table 1. Domestic and international profile of case company

\begin{tabular}{|l|l|l|l|l|l|}
\hline $\begin{array}{l}\text { Turnover EUR } \\
(\mathrm{m})\end{array}$ & $\begin{array}{l}\text { Merchandise } \\
\text { category }\end{array}$ & $\begin{array}{l}\text { Number of retail } \\
\text { stores in } \\
\text { domestic market }\end{array}$ & $\begin{array}{l}\text { Number of } \\
\text { international } \\
\text { retail stores }\end{array}$ & $\begin{array}{l}\text { Number of } \\
\text { international } \\
\text { countries - } \\
\text { wholesale }\end{array}$ & $\begin{array}{l}\text { Number of } \\
\text { international } \\
\text { countries-retail }\end{array}$ \\
\hline 10 & $\begin{array}{l}\text { Leather goods, } \\
\text { accessories }\end{array}$ & 10 & 3 & 20 & $2 *$ \\
\hline
\end{tabular}

Note: *At the time of the main case study research the firm had a retail presence in 2 international markets. They ceased retail trading in the UK during 2014. 